$\underline{\text { Araștırma Makalesi }}$

\title{
Antalya İlinin Bazı İlçelerindeki Sebze Alanlarında Bulunan Külleme Türlerinin Belirlenmesi
}

$\ddot{\mathbf{O z}}$

\author{
Ayşe TÜMAY ${ }^{1}, \quad$ Hülya ÖZGÖNEN ÖZKAYA ${ }^{2 *}$
}

Külleme etmenleri, sebze alanlarında görülen ve ekonomik olarak ürün kayıplarına neden olan önemli fungal hastalıklar arasında yer alır. Bu çalışma, Antalya'nın bazı ilçelerinde, yoğun olarak örtü altı yetiştiriciliği yapılan domates, biber, patlıcan, hıyar ve kabak gibi sebze ekiliş alanlarında görülen külleme türlerinin belirlenmesi amacıyla yapılmıştır. Çalışmada, sebze ekiliş alanlarında külleme etmenlerinin hastalık şiddeti (\%), hastalık oranı (\%) ve yaygınlı̆̆ (\%) belirlenmiş̧ir. Sörvey alanı olarak Antalya'da Aksu, Kepez, Konyaaltı, Muratpaşa ve Serik'teki sebze seralarından enfekteli yaprak örnekleri toplanmıştır. Tür teşhisleri ise, hastalıklı yaprak örneklerinde simptomatolojik ve mikroskobik teşhis kriterleri kullanılarak yapılmıştır. Sörvey alanlarında küllemenin hastalık oranları domateste \%4.0-19.3; biberde \%5.0-7.5; patlıcanda \%7.5-36.6; kabakta \%45.0-70.0 ve hiyarda \%22.0-50.0 arasında değişmiş̧ir. Küllemenin yaygınlık oranları domateste $\% 54.1$, biberde $\% 55.5$, patlıcanda $\% 44.4$, kabakta $\% 75.0$ ve hıyarda $\% 66.5$ olarak belirlenmiş̧ir. Yapılan incelemeler sonucunda, domates, biber ve patlıcanda Leveillula taurica (Lév) G. Arnaud (anamorph: Oidiopsis taurica (Lév.) E. S. Salmon), domateste Oidium neolycopersici L. Kiss., kabakgillerde Golovinomyces cichoracearum (de Candolle) Heluta (=Erysiphe cichoracearum) ve Podosphaera xanthii (Castagne) Braun \& Shishkof (=Sphaerotheca fuliginea) belirlenmiştir. Elde edilen bulgular işı̆̆ında külleme etmenlerinin sebze ekiliş alanlarında önemli düzeyde yaygın olduğu ve mücadele edilmesi gerektiği ortaya konulmuştur.

Anahtar Kelimeler: Antalya, Külleme hastalıkları, Solanaceae, Cucurbitaceae

\section{The Determination of Powdery Mildew Species in Vegetable Areas in Some Districts of Antalya Province}

\begin{abstract}
Powdery mildews are among the important fungal diseases seen in vegetable growing areas and cause yield losses economically. The aim of this study was to determine powdery mildew species in tomato, pepper, eggplant, cucumber and zucchini cultivation areas in Antalya central districts. In this study, disease severity $(\%)$, disease incidence $(\%)$ prevalence $(\%)$ were determined in vegetable cultivation areas. In surveyed areas, infected leaf samples were collected from vegetable cultivation areas in Aksu, Kepez, Konyaalt1, Muratpaşa and Serik in Antalya. Species identification was made by using symptomatological and microscopic diagnostic criteria on diseased leaf samples. Disease rates of powdery mildew in survey areas were $4.0-19.3 \%$ in tomatoes; $5.0-7.5 \%$ in pepper; $7.5-36.6 \%$ in eggplant; $45.0-70.0 \%$ in the zuccini and $22.0-50.0 \%$ in the cucumber. The prevalence of powdery mildew was $54.1 \%$ in tomato, $55.5 \%$ in pepper, $44.4 \%$ in eggplant, $75.0 \%$ in zuccini and $66.5 \%$ in cucumber. As a result of the investigations, powdery mildew species determined as Leveillula taurica (Lév) G. Arnaud (anamorph: Oidiopsis taurica (Lév.) E. S. Salmon) on tomato, pepper and eggplant; Oidium neolycopersici L. Kiss. on tomato, Golovinomyces cichoracearum (de Candolle) Heluta (=Erysiphe cichoracearum) and Podosphaera xanthii (Castagne) Braun \& Shishkof (=Sphaerotheca fuliginea) on cucurbitaceous plants. In the light of the findings, it has been shown that powdery mildews were important in vegetable cultivation areas and should be controlled.
\end{abstract}

Keywords: Antalya, Powdery mildews, Solanaceae, Cucurbitceae

ORCID ID (Yazar sirasına göre)

0000- 0002-0451- 1153, 0000- 0003- 3802- 3876

Yayın Kuruluna Geliş Tarihi: 26.11.2019

Kabul Tarihi: 18.06.2020

${ }^{1}$ Platin Kimya Mümessillik ve Dış Tic. A.Ş., Antalya

${ }^{2}$ Isparta Uygulamalı Bilimler Üniversitesi, Ziraat Fakültesi, Bitki Koruma Bölümü, Isparta

*E-posta: hulyaozgonen@isparta.edu.tr 


\section{Giriş}

Küllemeler tüm dünyada yaygın olan önemli fungal hastalıklar arasında olup pek çok konukçu bitkide belirti oluştururlar. Küllemeye neden olan patojenler, Fungi alemi, Ascomycota şubesi, Erysiphales takımında yer alır ve önemli bitki kayıplarına neden olurlar. Küllemeler, canlı hücre ve dokuları kullanarak yaşamını sürdüren obligat biyotrof patojenlerdir. Bitkinin enfekteli kısımlarında beyaz tozsu bir görüntü oluşturmaları nedeniyle külleme adını almışlardır. Genel olarak bitkilerde, gelişim geriliği nedeniyle dokuların erken yaşlanmasına, bodurlaşmaya, yapraklarda kıvrılmaya renk değişimine ve tomurcukların dökülmesine neden olurlar. Yaprak yüzeyi üzerinde oluşturdukları belirtiler nedeniyle fotosentez alanını azaltarak bitkide gelişme geriliklerine neden olurlar. Küllemeler otsu bitkilerden orman ağaçlarına kadar geniş yelpazedeki konukçu bitki türleri üzerinde yaygın olup aynı familyadan tek bir bitkiyi ya da akraba bitki türlerini enfekte ederler. Konukçularına özelleşmiş 850'den fazla külleme türünün mevcut olduğu bildirilmiştir (Agrios, 1997; Erper ve ark., 2012; Sezer, 2016; Erper ve ark., 2019).

Sebzelerde Patlicangiller (Solanaceae) ve Kabakgiller (Cucurbitaceae) familyalarında külleme hastalığı oldukça yaygındır. Patlıcangiller familyasında, küllemeye neden olan hastalık etmeni Leveillula taurica olup, konukçuları biber, patlıcan, patates ve domatestir (Anonim, 2008a). Kabakgiller familyasında, küllemeye neden olan hastalık etmenleri Golovinomyces cichoracearum (=Erysiphe cichoracearum) ve Podosphaera xanthii (=Sphaerotheca fuliginea (Schltdl.) Pollacci)'dir. Konukçuları hıyar, kabak, kavun ve karpuzdur (Anonim, 2008b).

Külleme hastalığı sera ve açı alanda yetiştirilen sebzelerde yaygın olarak görülmektedir. Serada sebze yetiştiriciliğinde dönemsel olarak mücadele edilmesi gereken bir hastalık konumundadır. Türkiye'de seracılık ve örtüaltı üretimin mevcut durumuna bakıldığında, 2017 yılında 30.2 milyon ton sebze üretimi gerçekleşmiştir FAO, 2017). Bu üretimin 23.4 milyon tonu açıkta, 7.4 milyon tonu örtüaltında üretilmiş olup, Antalya $\% 51$ 'lik payla (3.2 milyon ton) birinci sıradadır. Bu ilimizi sırasıyla, Mersin \%18 (1 milyon ton), Adana \%11 (670 bin ton) ve Muğla \%9 (527 bin ton) illeri takip etmektedir. $\mathrm{Bu} 4$ ildeki toplam örtü altı üretimi yaklaşık 5.4 milyon ton olup; ülkemiz toplam örtüaltı üretiminin yaklaşık \%90'nını oluşturmaktadır (Anonim, 2019a).

Antalya ilinde örtü altı yetiştiriciliği yapılan domates, biber, patlıcan, hiyar ve kabak üretim alanlarında külleme hastalığı oldukça yaygındır. Hastalık, ilerleyen aşamalarda sebzelerde ekonomik zarara neden olmakta ve ürün kayıpları meydana gelmektedir.

Sebzelerde külleme ile mücadelede dayanıklı çeşit yetiştirilmesi tavsiye edilmektedir. Küllemeler iyi hava sirkülasyonu, dengeli gübreleme gibi kültürel pratiklerle kontrol edilebilmektedir. Külleme enfeksiyonları sebze ekiliş alanlarında görülür görülmez kimyasal mücadele uygulanmalıdır. Kimyasal mücadelede genellikle koruyucu veya eradikant fungisitlerden kresoxim-methyl, triadimenol, kükürt, penconazole, cyflufenamid, azoxystrobin aktif maddelerini içeren ticari ürünlerin $\mathrm{WDG}=\mathrm{WG}, \mathrm{WP}, \mathrm{EC}$, EW, SC gibi farklı formülasyonlarındaki bitki koruma ürünleri kullanılmaktadır (BKÜ Veri Taban1, 2019).

$\mathrm{Bu}$ çalışmada, Antalya iline bağlı bazı ilçelerde, domates, biber, patlıcan, hıyar ve kabak ekiliş alanlarında küllemeye neden olan hastalık etmenlerinin makroskobik ve mikroskobik yöntemler kullanılarak geleneksel tanı yöntemlerine göre tür teşhislerinin yapılması; örnek alınan alanlarda hastalık şiddetinin değerlendirilmesi, seralarda hastalık oranı ve merkez ilçedeki örnekleme yapılan mevkilerde yaygınlıklarının belirlenmesi amaçlanmıştır.

\section{Materyal ve Yöntem}

$\mathrm{Bu}$ çalışmada kullanılan hastalıklı yaprak örnekleri Antalya ilinin Muratpaşa, Konyaaltı, Aksu, Döşemealtı, Serik ve Kepez ilçelerinde domates, biber, patlican, hiyar ve kabak 
üretimi yapılan alanlardan toplanmıştır. Taze yaprakların incelenmesi ve herbaryum hazırlığı için gazete kağıtları, polietilen poşetler kullanılmıştır. Laboratuvar çalışmaları için, lam, lamel, ince şeffaf bant, ucu küt bir bistüri, tek taraflı bir jilet, beher, elek, pens, mikroskop iğnesi, 1şık mikroskobu (Nikon) ve örneklerin boyanmasında laktofuksin kullanılmıştır.

\section{Sörvey çalıșmaları}

Külleme ile enfekteli yaprak örnekleri, Antalya iline bağlı bazı ilçelerde örtüaltı domates, biber, hıyar, patlıcan ve kabak ekiliş alanlarından temin edilmiştir. Bunun için Antalya İl Tarım ve Orman Müdürlügü̈'ne ait 2018 yılı örtü altı sebze ekiliş alanlarında üretimi yapılan ürünlere ait veriler alınmıştır. Alınan veriler doğrultusunda sörvey alanı belirlenmiştir. Domates, patlıcan, biber, kabak ve hıyar yetiştiriciliğinin yapıldığ toplam 74648 da alandan örnek toplanmıștır. $\mathrm{Bu}$ bağlamda domates yetiştirilen 37 , biber yetiştirilen 9, patlican yetiştirilen 7 , kabak yetiştirilen 4 ve hıyar yetiştirilen 6 olmak üzere toplam 63 seradan örnek alınmıștır.

(Çizelge 1). Hastalık belirtisi gösteren seralardan bölümlü örneklemeye göre bitki örnekleri alınmıştır (Bora ve Karaca, 1970).

Sörvey alanlarından Mart-Kasım ayları arasında hastalıklı yaprak örnekleri toplanmıştır. Seralara girildiğinde öncelikle bitkilerin yapraklarında külleme varlığının olup olmadığı incelenmiştir. Özellikle yapraklarda ve bitkinin değişik kısımlarında beyaz, tozumsu bir görüntü aranılmış ve hasat sonuna doğru varsa çıplak gözle siyah küre şeklindeki Chasmothecium varlığ 1 görülmeye çalışılmıştır. Daha sonra toplanan taze yaprak örnekleri gazete kağıtlarına sarılarak polietilen poşetlere konulmuştur. Laboratuvara getirilerek buzdolabında inceleme yapılıncaya kadar saklanmıştır. Bunun yanısıra bitkiler herbaryum tekniklerine göre kurutulmuştur. Kurutma işlemi biten örnekler ağzı açık beyaz zarflar içerisine konulmuştur. Her bir örnek toplandığı yer, toplayan kişi, ilçe, tarih, alan, bitki adı varsa çeşidi olmak üzere etiketlenmiştir. Böylelikle örneklerin istenilen zamanda kullanılabilmesi sağlanmıştır. Örneklerin bulunduğu zarflar bitki çeşitlerine göre numaralandırılmıştır. $\mathrm{Bu}$ şekilde örneklerde teşhiş amaçlı kullanım kolaylığı sağlanmıştır. Çizelge 1'de Antalya merkez ilçelerdeki sera alanlarından toplanan örnek sayıları verilmiştir.

\section{Sebze alanlarında küllemenin hastalık oranı ve yaygınlığının belirlenmesi}

Merkez ilçelerdeki mevkilerde Patlıcangiller ve Kabakgiller familyasında görülen kültür bitkilerindeki küllemelerin genel olarak hastalık şiddetinin değerlendirilmesi için sera içindeki bitkilerde tesadüfi olarak 100 bitki üzerinde $0-5$ skalasına göre değerlendirme yapılmıştır Skala $0=$ Yaprakta hastalık yok; $1=$ Yaprakta \%0-1 külleme lekesi var; 2= Yaprakta \%2-5 külleme lekesi var; 3= Yaprakta \%6-20 külleme lekesi var; 4= Yaprakta \%21-40 külleme lekesi var; 5= Yaprakta \%40'tan fazla külleme lekesi var şeklindedir (Anonim, 2016b).

Skala değerlendirmeleri sonucu göre Townsend-Heuberger (1943) formülü uygulanarak \% hastalık şiddeti bulunmuştur. Hastalık şiddeti (\%) aşağıdaki formül ile hesaplanmıştır.

$$
\text { Hastalık Şiddeti }(\%)=\frac{\Sigma(n \cdot v)}{N \cdot V} \times 100
$$

Formülde; $\mathrm{n}$ skala değerini, $\mathrm{v}$ skalaya giren bitki sayısını, $\mathrm{N}$ en yüksek skala değerini ve $\mathrm{V}$ toplam bitki sayısını ifade etmektedir.

Antalya iline bağlı bazı ilçelerde sera içerisinde tesadüfi olarak hasta bitkiler sayılmış ve hastalık oranı (\%) hesaplanmıştır. Yine, mevkilerde hastalığın görüldügü seralar belirlenerek ortalama hastalık yaygınlığ $(\%)$ hesaplanmıştır (Karman, 1971).

\section{Hastalıklı bitki örneklerinin incelenmesi ve teşhiste kullanılan kriterler}

Külleme ile enfekteli taze bitki örnekleri üzerinde, preparat hazırlanmak üzere tek taraflı bir jilet yardımıyla misel ve sporların bulunduğu beyaz tabakadan kazıma yapılmıştır. Küllemelerin teşhisinin daha kolay yapilabilmesi amaciyla, lam üzerine pembe renkli laktofuksin damlatılmıştır. Damla üzerine jilet yardımıyla misel ve sporlar 
aktarılmıştır. Lam üzeri bir lamel ile kapatılmıştır. Hava alımını engellemek ve bozulmayı geciktirmek amaciyla lamelin etrafı sırlanmıştır. Ayrıca şeffaf bant ile misel ve spor kitlesinden sabit preparat hazırlanmıştır. Hazırlanan preparatlar, etiketlenerek saklanmıştır. Laboratuvarda bir 1 şık mikroskobu yardimiyla (Nikon) preparatlar incelenmiştir. Külleme etmenlerinde, varsa eşeyli üreme yapıları olan Chasmothecium varlığının mikroskop altında gözlenmesi amaciyla, Chasmothecium içeren yaprak örnekleri mikroskop altına yerleştirilmiştir (Yamaoka ve Takeuchi, 1999; Braun ve ark., 2002; Heffer ve ark., 2006).

\section{Bulgular ve Tartışma}

Sörvey Alanlarında Küllemenin Hastalık Şiddeti ve Yaygınlık Oranları

Sörvey yapılan sebze üretim alanlarında tespit edilen hastalık şiddeti, hastalık oranı ve yaygınlık oranları Çizelge 1'de verilmiştir. Domatesteki küllemenin ortalama hastalık şiddeti \%3.5-25 arasında değişmiştir. Hıyar ve kabakta merkeze yakın alanlarda küllemenin en yüksek hastalık şiddeti sırasıyla \%46 ve $\% 55$ oranlarında olmuştur. Küllemenin hastalık oranı domateste \%4.0-19.3 arasinda olmuştur. Hastalık oranı kabakta Merkez ve Aksu'da sirasiyla \%45 ve \%70.0 oranlarında olmuştur. Hastalık yaygınlığ değerlendirildiğinde Merkez ilçede külleme kabakta en yüksek \%75 oranında bulunurken en düşük patlıcanda $\% 44.4$ oranında belirlenmiştir.

Ozan ve Maden (2005)'in Ankara ilinin domates ekiliş alanlarında yapmış olduğu çalışmada hastalıklı yapraklarda en fazla küllemenin yaygınlık oranını \%49.8 olarak belirlemiştir. Yine, Kırbağ ve Turan (2005), Malatya ilinde domateslerde küllemenin \%10 oranında bulunduğunu tespit etmiştir.

\section{Sebze Ekiliş Alanlarında Görülen Külleme Türleri \\ Leveillula taurica (Lév) G. Arnaud}

Sistematikteki yeri (Anamorph=Oidiopsis taurica (Lév.) E. S. Salmon (EPPO, 2019a)

Alem: Fungi

Şube: Ascomycota

Altşube : Pezizomycotina

Sinıf: Leotiomycetes
Takım: Erysiphales

Familya: Erysiphaceae

Cins: Leveillula

Tür: Leveillula taurica

Konukçuları: Söryey alanlarında Solanaceous bitkilerden domates, biber ve patlicanda görülmüştür.

Belirtileri: Külleme ile enfekteli domates, biber ve patlican bitkilerinin yaprakları makroskobik olarak incelenmiştir. Domateste yaprak yüzeyinde bulunan beyazımsı miseller düzensiz şekilde olup dağınık olarak görülmüştür. Hastalığın ilerlemiş olduğu yapraklarda renk grimsi kahverengi olarak gözlemlenmiştir. Genellikle yaşlı yaprakların alt yüzeyinde külleme belirtilerine rastlanmıştır. Bazı domates bitkilerinin yaprakları şiddetli enfeksiyon nedeniyle kıvrıldığı ve deformasyona uğradığ 1 görülmüştür. Biber bitkisinde yaşlı yaprakların alt yüzeyinde, beyaz renkli tozumsu yapılar görülmüştür. Miseller düzensiz şekilde olup, bazı yapraklarda tüm yüzeyi kaplamıştır. Ağır enfekteli yapraklarda renk kahverengi olarak, yaprak kenarları yukarı doğru kıvrılmış olarak gözlemlenmiştir. $\mathrm{Bu}$ durumun bazı biber bitkilerinin meyvelerinde deformasyona neden olduğu görülmüştür. Genç-taze yaprakların alt yüzeyinde külleme belirtilerine rastlanmamıştır. Patlıcanda yapraklarda, yuvarlak beyaz lekecikler şeklinde, yaprak yüzeyine yapışmış olarak görülmüştür. Hastalığın ilerlemiş olduğu yapraklarda ise grimsi kül rengi olarak gözlemlenmiştir. Bazı yapraklar, hastalığın ilerlemesinden dolayı pörsümüş, kurumuş ve aşağ 1 sarkmış ve sonunda dökülmüș olarak görülmüștür (Şekil 1, Şekil 2, Şekil 3).

Mikroskobik özellikleri: Tür bazında teşhis yapmak amaciyla laboratuvarda 1 şı mikroskobu altında yapılan incelemede, domatesten alınan örneklerde konidiler fiçışişe şeklinde elipsoid olarak, çoğu zaman düzensiz ve birbirine geçmiş halde gözlemlenmiştir. Uzantılar, basit hif şeklindedir. Leveillula taurica'nın konidi boyutları 50-70 x16-24 $\mu \mathrm{m}$ olup konukçu bitkiye göre değişmekle birlikte, çalışmada ortalama en $17,8 \mu \mathrm{m}$, ortalama boy $54,6 \mu \mathrm{m}$ 
olarak ölçülmüștür. Biber bitkisindeki küllemeden hazırlanan preparatlarda ortalama konidi boyutlar1 en $17,6 \mu \mathrm{m}$, ortalama boy 56,2 $\mu \mathrm{m}$ olarak ölçülmüsstür. Patlıcanda genellikle Leveillula taurica'nın konidi boyutları 40-80 x12-19 $\mu \mathrm{m}$ olup konukçu bitkiye göre değişmekle birlikte, çalışmada ortalama konidi boyutları en $15,9 \mu \mathrm{m}$, boy $49,3 \mu \mathrm{m}$ olarak ölçülmüştür. Chasmothecium görülmemiştir. Yapılan incelemeler sonucunda etmenin Leveillula taurica olduğu teşhis edilmiştir (Şekil 4).

Çizelge 1. Küllemenin hastalık şiddeti, hastalık oranı ve yaygınlığ 1

\begin{tabular}{|c|c|c|c|c|c|}
\hline Bitki & Mevkii & $\begin{array}{c}\text { Örnekleme } \\
\text { yapılan sera } \\
\text { sayısı }\end{array}$ & $\begin{array}{l}\text { Hastalık } \\
\text { şiddeti } \\
\text { (\%) }\end{array}$ & $\begin{array}{c}\text { Hastalık } \\
\text { oranı (\%) }\end{array}$ & $\begin{array}{c}\text { Hastalık } \\
\text { yaygınlığı } \\
(\%)\end{array}$ \\
\hline \multirow{5}{*}{ Domates } & $\begin{array}{l}\text { Kepez (Gaziler, Altınova } \\
\text { Varsak) }\end{array}$ & 11 & 18.0 & 19.3 & \multirow{5}{*}{54.1} \\
\hline & Aksu (Kundu, Yurtpinar) & 15 & 25.0 & 11.6 & \\
\hline & Muratpaşa (Güzelbağ) & 3 & 3.5 & 4.0 & \\
\hline & Serik & 8 & 8.0 & 6.1 & \\
\hline & Toplam & \multicolumn{2}{|l|}{37} & & \\
\hline \multirow{4}{*}{ Biber } & $\begin{array}{l}\text { Merkez (Muratpaşa, } \\
\text { Konyaaltı, Kepez) }\end{array}$ & 3 & 2.5 & 5.0 & \multirow{4}{*}{55.5} \\
\hline & Aksu (Kurşunlu civarı) & 2 & 12.0 & 7.5 & \\
\hline & Serik & 4 & 24.0 & 6.3 & \\
\hline & Toplam & \multicolumn{2}{|l|}{9} & & \\
\hline \multirow{4}{*}{ Patlican } & Kepez & 2 & 5.6 & 10.0 & \multirow{4}{*}{44.4} \\
\hline & $\begin{array}{l}\text { Konyaaltı } \\
\text { (Çakırlar, Doyran) }\end{array}$ & 3 & 4.5 & 36.6 & \\
\hline & $\begin{array}{l}\text { Muratpaşa (Havalimanı } \\
\text { civarı) }\end{array}$ & 2 & 37.0 & 7.5 & \\
\hline & Toplam & \multicolumn{2}{|l|}{9} & & \\
\hline \multirow{3}{*}{ Kabak } & $\begin{array}{l}\text { Merkez (Muratpaşa, } \\
\text { Kepez) }\end{array}$ & 2 & 55.0 & 45.0 & \multirow{3}{*}{75.0} \\
\hline & Aksu (Çamköy) & 2 & 15.0 & 70.0 & \\
\hline & Toplam & 4 & & & \\
\hline \multirow[t]{3}{*}{ Hiyar } & $\begin{array}{l}\text { Merkez } \\
\text { (Muratpaşa, } \\
\text { Konyaaltı, Kepez) }\end{array}$ & 5 & 46.0 & 22.0 & \multirow[t]{3}{*}{66.5} \\
\hline & Aksu (Çamköy) & 1 & 35.0 & 50.0 & \\
\hline & Toplam & 6 & & & \\
\hline
\end{tabular}




\section{Belirlenmesi}



Şekil 1. Leveillula taurica'nın domatesteki belirtisi Şekil 2. Leveillula taurica'nın biberdeki belirtisi



Şekil 3. Leveillula taurica'nın patlıcandaki belirtisi

Yaptığımız çalışma ile paralel olarak, Ozan ve Maden (2005)' in Ankara ilinin domates ekiliş alanlarında yapmış olduğu çalışmada, hastalıklı yapraklarda en fazla yayginlık gösteren fungal etmenin $\% 49.8$ oranı ile Leveillula taurica olduğunu bildirmiştir. Ozan ve Maden (2006) yaptıkları bir diğer çalışmada domateste Leveillula taurica, Oidium neolycopersici ve Oidium lycopersici'nin külleme etmenleri olduğunu fakat ülkemizde ise yalnızca Leveillula taurica'nın yaygın olarak görüldüğünü bildirmiştir. Araştırma ile benzerlik gösteren Yörükoğlu (2011) çalışmasında, Küçük Menderes Havzasında salçalık biberlerde sorun oluşturan fungal etmenler belirlenmiş ve açık tarlada üretimi yapılan ve her 100 biber bitkisinin 89'unda külleme hastalığının olduğunu, \%14'lük bir oran ile sinırlı düzeyde hastalığın mevcut olduğunu bildirmiştir. Ozan ve Aşkın (2006), Ankara,
Şekil 4. Leveillula taurica'nın konidileri

Çankırı, Zonguldak ve Bartın İlleri'nde 2003-2004 yıllarında yaptıkları sörvey çalışmaları sonucunda, Bartın İli patlıcan seralarında \%7.3 yayginlık oranıyla patlıcangillerde külleme hastalık etmeni Leveillula taurica'ya rastlandığını ve ekonomik ürün kayıplarına neden olduğunu bildirmiştir.

\section{Oidium neolycopersici L. Kiss}

Sistematikteki yeri (EPPO, 2019 b).

Alem: Fungi

Şube: Ascomycota

Altşube: Pezizomycotina

Sinif: Leotiomycetes

Takım: Erysiphales

Familya: Erysiphaceae

Cins: Oidium

Cins: Oidium (anamorphic genus)

Tür: Oidium neolycopersici

Konukçuları: Sörvey yapılan alanlarda domates bitkilerinde rastlanmıştır. 


\section{Antalya İlinin Bazı İlçelerindeki Sebze Alanlarında Bulunan Külleme Türlerinin Belirlenmesi}

Belirtileri: Domateste küllemeye neden olan bazı türler Oidium'lardır. Hastalık, petiollerde, gövde üzerinde ve yaprakların alt ve üst yüzeylerinde beyaz renkte koloniler oluşmaktadır. Üzerindeki koloniler nedeniyle yapraklar grimsi beyaz bir renk alabilir. Enfekteli alanda, altta yatan doku başlangıçta mor renge dönüşebilir fakat sonrasında klorotikleşmeye ve nekrotikleşmeye başlar. Şiddetli enfeksiyonlarda yapraklarda kıvrilma ve deformasyona neden olur (Şekil 5).

Mikroskobik özellikleri: Oidium neolycopersici yalnızca konidi üretir; konidi ölçüsü 22-46 x10-20 $\mu$ m'dir ve elipsoidoval şeklindedir. Bu türler dünyada oldukça yaygındır ve dünyanın pek çok bölgesinde domates üzerinde bulunabilir (Şekil 6). Çalışmamızda ortalama konidi ölçüleri boy $29,5 \mu \mathrm{m}$ ve en $15 \mu \mathrm{m}$ olarak ölçülmüş ve literatürde verilen konidi ölçüleri ile uyumlu bulunmuştur (Kiss ve ark., 2001). Bu tür Avustralya'da tespit edilmiştir (Wicks ve Clare, 1981).

Türkiye'de $O$. neolycopersici ilk kez Yolageldi ve ark. (2008) tarafindan Ege Bölgesi'nde hidroponik domates seralarında kaydedilmiştir. Salvucci ve ark. (2016)'nin bildirdiğine göre, Kaliforniya'da domateste küllemeye neden olan iki etmen tarlada primer olarak Leveillula taurica ve serada Oidium neolycopersici hastalık meydana getirmektedir. Ayn1 zamanda Oidium lycopersici (sin: Euoidium lycopersici) de domatesi enfekte etmektedir. Bu tür daha önce Kiss ve ark. (2001) tarafindan Avustralya'da rapor edilmiştir. Kaliforniya'da 2015 y1lında tarlada yetiştirilen domateslerde şiddetli külleme enfeksiyonları meydana gelmiş ve hastalıklı bitkilerin yapraklarında klorotik ve daha sonra nekrotik lezyonlar gözlenmiştir. Külleme belirtilerinin önceleri $L$. taurica'nın meydana getirdiği enfeksiyonlardan kaynaklandığı düşünülmüştür. $O$. lycopersici'nin sporulasyonu ayn zamanda abaxial yaprak yüzeyinde gözlenmiştir. Bunun yanında, bazı bitkilerde adaxial yaprak yüzeyi ve gövde üzerinde Oidium spp.'nin gelişimine benzer küçük beyaz lezyonlar şeklinde epifitik miselyum ve konidi kitlesi gözlenmiştir. Daha sonra yapılan detaylı araştırmalar sonucunda fungus $O$. lycopersici olarak tanımlanmıştır. Yapılan çalışmalar sonucunda, Kaliforniya'da $L$. taurica'nın primer olarak epidemilerden sorumlu olduğunu ancak bu üç türün bitkileri enfekte edebileceği ortaya konulmuştur.
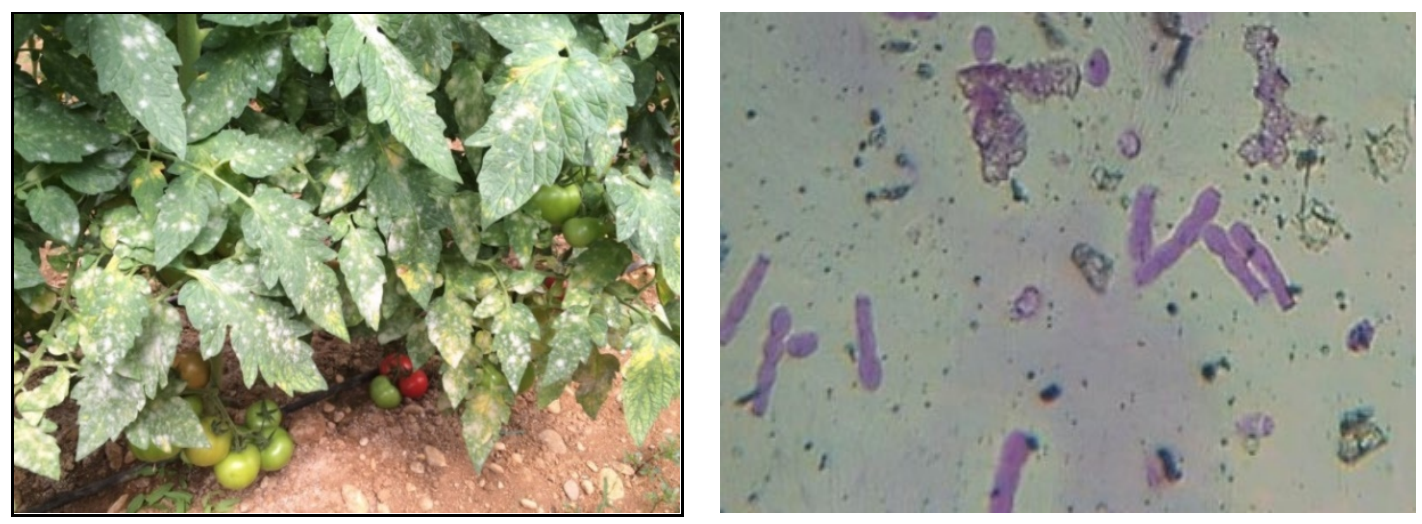

Şekil 5.Oidium neolycopersici’nin belirtileri Şekil 6. Oidium neolycopersici’nin mikroskobik görüntüsü

\section{Podosphaera xanthii (Castagne) Braun \& Shishkof}

(Sin: Sphaerotheca fluginea Jaczewski) Sistematikteki yeri (EPPO, 2019 c).

Alem: Fungi

Şube: Ascomycota

Altşube: Pezizomycotina 
Sinif: Leotiomycetes

Takım: Erysiphales

Familya: Erysiphaceae

Cins: Podosphaera

Tür: Podosphaera xanthii

Konukçuları: Sörvey yapılan alanlarda hıyar ve kabak bitkilerinde görülmüştür.

Belirtileri: Enfekteli kabak bitkilerinin yaprakları makroskobik olarak incelenmiştir. Enfeksiyonun görüldügü ilk yapraklar, yaşlı yaprakların alt yüzeyi olup, yaprak yüzeyinde beyaz renkli tozumsu spor kolonileri kolaylıkla görülmüştür. Miseller düzensiz şekilde olup, bazı yapraklarda tüm yüzeyi kaplamıştır. Genç ve taze yaprakların alt yüzeyinde, bitkinin gövde ve meyvesinde külleme patojenlerine rastlanmamıştır (Şekil 7).

Mikroskobik özellikleri: Tür bazında teșhis yapmak amacıyla laboratuvarda 1 șik mikroskobu altında yapılan incelemede, konidiler yumurta şeklinde, tombul ve yuvarlağımsı, düzensiz, saydam, bazen zincir şeklinde ve bazı noktalarda birbirine geçmiş halde gözlemlenmiştir. Uzantılar, basit hif şeklindedir. Dallanmış konidioforlara rastlanmamıştır. Podosphaera xanthii'nin konidi boyutları 25-37 x 14-25 $\mu \mathrm{m}$ ölçüsünde, saydam, elipsoid ve fiçı şeklindedir. Konidi boyutları kabak çeşitlerine göre değişmekle birlikte, yapılan incelemeler sonucunda, ortalama konidi boyutları en $16,2 \mu \mathrm{m}$, ortalama boy $27,3 \mu \mathrm{m}$ olarak ölçülmüştür ve etmenin dünya genelinde ve Türkiye de kabaklarda yaygın olarak görülen ve külleme hastalığına neden olan Podosphaera xanthii olduğu teşhis edilmiştir (Şekil 8).

Çalışmamız ile benzerlik gösteren Yüceson (2017)'un yüksek lisans tez çalışmasında, Batı Akdeniz ve Doğu Akdeniz arasında yetişen yerel, yabani ve ticari kabak çeşitleri üzerinde makroskobik ve mikroskobik incelemeler yapmış, Antalya İli Gazipaşa ilçesinden izole edilen patojenin moleküler analizler sonucunda \%99 oranında Podosphaera xanthii olduğu bildirilmiştir. Kırbağ ve Kürşat (2011), Elazığ İli Sivrice ilçesi'nde, külleme patojeninin hastalık oluşturduğu konukçu bitki örnekleri toplanarak yapılan mikroskobik incelemeler sonucunda Erysiphaceae familyasına ait 29 külleme türü içerisinden bir etmen Podosphaera xanthii olarak tespit edilmiştir.

Kırbağ ve Turan (2005), Malatya İli'nde, kavun, karpuz, kabak ve hiyar yetiştiriciliği yapılan alanlarda külleme hastalığına neden olan Erysiphe cichoracearum ve Sphaerotheca fluginea patojenlerinin yaprak ve sürgünlerde ortalama $\% 10$ oranında bulunduğunu bildirmiştir.



Şekil 7. Podosphaera xanthii'nin kabakta belirtisi

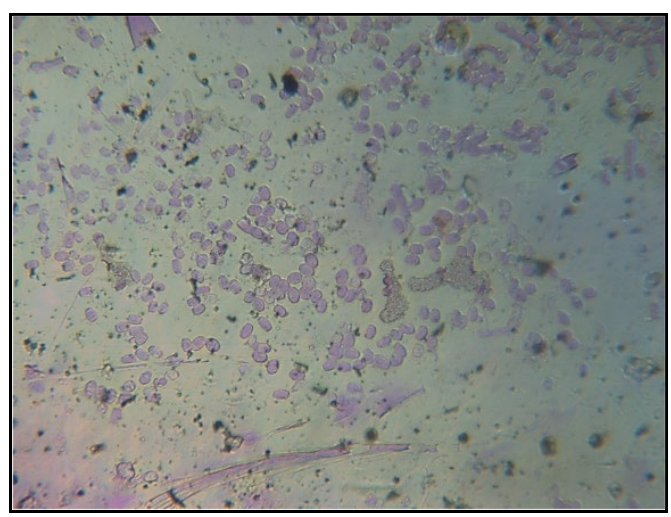

Şekil 8. Podosphaera xanthii'nin konidileri 
Golovinomyces cichoracearum

(de

Candolle) Heluta

(Sin: Erysiphe cichoracearum de Candolle) Sistematikteki yeri (EPPO, 2019 d).

Alem: Fungi

Şube: Ascomycota

Altşube : Pezizomycotina

Sinıf: Leotiomycetes

Takım: Erysiphales

Familya: Erysiphaceae

Cins: Golovinomyces

Tür: Golovinomyces cichoracearum

Konukçuları: Sörvey yapılan alanlarda hıyar ve kabakta gözlemlenmiştir.

Belirtileri: Külleme ile enfekteli kabak bitkilerinin yaprakları makroskobik ve mikroskobik olarak incelenmiştir. Enfeksiyonun görüldüğ̈̈ ilk yapraklar, yaşlı yaprakların alt yüzeyi olup, yaprak yüzeyinde beyaz renkli tozumsu spor kolonileri un serpilmiş olarak kolaylıkla görülmüştür. Lekeler bazı yapraklarda yuvarlak şekilde olup, bazı yapraklarda tüm yüzeyi kaplamıştır ve düzensiz şekillerde gözlemlenmiștir. Genç taze yaprakların alt yüzeyinde, bitkinin gövde ve meyvesinde külleme patojenlerine rastlanmamıştır (Şekil 9).

Mikroskobik özellikleri: Tür bazında teşhis yapmak amaciyla laboratuvarda 1şı mikroskobu altında yapilan incelemede, konidiler yumurta şeklinde, tombul ve yuvarlağımsı, düzensiz, saydam, bazen zincir şeklinde ve bazı noktalarda birbirine geçmiş halde gözlemlenmiştir. Uzantılar, basit hif şeklindedir. Dallanmış konidioforlara rastlanmamıștır.

Kabakgillerde G. cichoracearum konileri elipsoid-fıçı şeklinde olup, konidi boyutları genellikle 25-45 x 14-25 $\mu$ m'dir. Konidi boyutları kabak çeşitlerine göre değişmekle birlikte ortalama en $15.6 \mu \mathrm{m}$, boy $24.4 \mu \mathrm{m}$ olarak ölçülmüştür. Yapılan incelemeler sonucunda, hiyar ve kabak bitkilerinde külleme hastalığına neden olan etmenin $G$. cichoracearum olduğu teşhis edilmiştir (Şekil 10).

Çalışmamız ile paralel olarak, Kırbağ ve Turan (2005), Malatya ili sebze üretim alanlarında fungal hastalı etmenlerinin belirlenmesine yönelik yaptığı araştırmada, kavun, kabak ve hiyar yaprak ve sürgünlerinde küllemeye neden olan Golovinomyces cichoracearum ve Podosphaera xanthii \%10 oranında rastlandığını, salatalıklarda küllemeye neden olan etmenin Golovinomyces cichoracearum olduğunu bildirmiştir. 


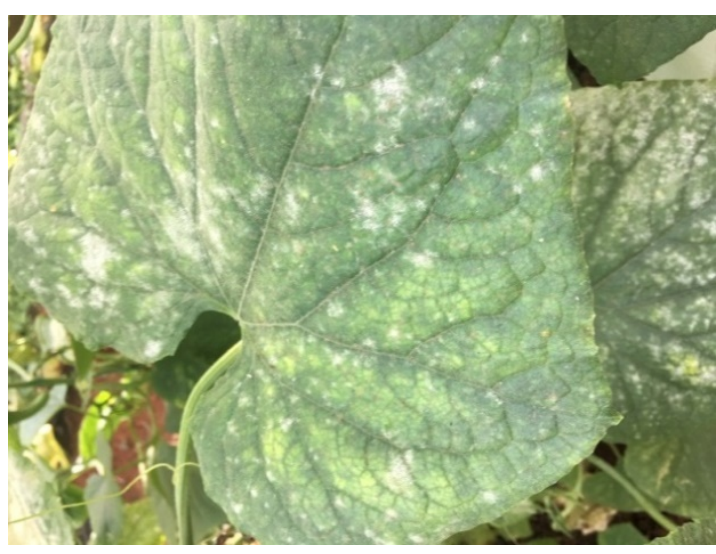

Şekil 9. Golovinomyces cichoracearum belirtisi



10. Golovinomyces cichoracearum'un konidileri

\section{Sonuç}

$\mathrm{Bu}$ çalışmada Antalya iline bağlı bazı ilçelerde sebze yetiştiriciliği yapılan seralarda külleme türlerinin belirlenmesi amaçlanmıştır. Külleme etmenleri tüm dünyada yaygın olup sebze ekiliş alanlarında ciddi problem oluşturan fungal hastalıklardandır. Son dönemlerde küresel ısınmanın etkisiyle tarımsal üretimde daha da önemli bir konumda yer almakta ve zarar düzeyi artan fungal etmen olarak anılmaktadır. Ülkemizde de örtüaltı tarımın yoğun olarak yapıldığı Antalya ilinin bazı ilçelerinde domates, biber, kabak, hıyar ve patlıcan ekiliş alanlarında farklı külleme etmenleri belirlenmiştir.

Yapılan çalışmalar sonucunda, Antalya iline bağlı bazı ilçelerden toplanan hastalıkla enfekteli yapraklar üzerinde yapılan makroskobik ve mikroskobik teşhislerde domates, biber ve patlican bitkilerinde Leveillula taurica (Lev.) G. Arnaud, domateste Oidium neolycopersici, kabak ve hiyarda Podosphaera xanthii ve Golovinomyces cichoracearum etmenleri bulunmuştur. Ülkemizde domateste $O$. lycopersici Cooke \& Massee külleme türüne rastlandığına dair bir kayıt bulunmamıştır. Ancak, Oidium neolycopersici L. Kiss ülkemizde domateste Yolageldi ve ark. (2008) tarafindan yapılan bir çalışmada Ege Bölgesi'nde hidroponik domates serasında rastlanmış ve ilk kayıt yapılmıştır.
Sörveylerimiz sirasinda $O$. neolycopersici'nin bulunduğuna dair makroskobik ve mikroskobik özelliklerine uygun bulgular elde edilmiş ve böylece Antalya iline bağlı merkez ilçede tespit edilmiş̧ir. Ancak geleneksel metodlarla yapılan teşhislerin moleküler yöntemlerle de desteklenmesi gerektiği düşünülmektedir.

Sebze üretiminde külleme etmenleriyle mücadele edilmektedir. Külleme etmenlerine karşı en yoğun kimyasal mücadele yapılmakta ve bu yöntemle hastalık başarı ile kontrol altına alınmaktadır. Ancak dönemsel olarak hastalık baskısı yüksek olduğunda mücadele güçlügü yaşanmaktadır.

Sebzelerde külleme hastalığı ile mücadelede bazı kontrol yöntemleri kullanılmaktadır. En başta hastalıkla mücadelede kültürel önlemler uygulanmalıdır. Bu uygulamalar sağlıklı üretim materyalinin kullanılması, etmenin konukçusu olmayan bitkilerle münavebesi, hastalıklı bitki artıklarının yetiştirme ortamından uzaklaştırılması ve imha edilmesi, sik ekim-dikimden kaçınılması, sera içindeki yabancı otların uzaklaştırılması, toprakta hava akımının sağlanmas1, dengeli gübreleme şeklindedir. Bunların yanı sıra sebze küllemelerine karşı dayanıklı çeşit kullanılması önerilir. 
Küllemelere karşı bazı mikoparazitlerin etkinliği bilinmektedir. En etkili mikoparazitler Ampelomyces quisqualis, Sporothrix flocculosa, Stephanoascus rugulosus, Tilletiopsis türleri ve Verticillium lecanii (Hijwegen, 1992; Falk ve ark., 1995; Verhaar ve ark., 1997; Jones ve ark., 2001) olup, bunlar bitki direncini uyarır, patojen üzerinde doğrudan etki etmektedir.

Küllemelere karşı biyolojik mücadele önerilmekte ve bunlara karşı ruhsatlı preparatlar da bulunmaktadir. Patlicangillerde külleme (Leveillula taurica), Kabakgillerde külleme (Erysiphe cichoracearum ve Sphaerotheca fuliginea) ruhsatli, $5 \mathrm{~g} / 100 \mathrm{~L}$ su dozunda WG formülasyonlu $\quad \% 58,5 \times 10^{9} \quad \mathrm{cfu} / \mathrm{ml}$ Ampelomyces quisqualis izolat m-10, 125 $\mathrm{g} / 100 \mathrm{~L}$ su dozunda WP formülasyonlu Bacillus subtilis Y 1336, $1400 \mathrm{ml} / \mathrm{da}$ dozunda SC formülasyonlu \%1,34 Bacillus subtilis QST 713 1rk1, $200 \mathrm{ml} / 100 \mathrm{~L}$ su dozunda SC formülasyonu 224,6 g/l Reynoutria spp. ekstraktı biyolojik fungisitlerin kullanılması önerilmektedir (BKÜ Veri Tabanı, 2019).

Son yıllarda bitki hastalıklarıyla mücadelede bitki ekstraktlarının kullanılması yaygınlaşmıştır. Bitki ekstraktlarının küllemelere karşı biyolojik mücadele etmenleriyle kombine edilerek kullanılması konusunda çalışmalar bulunmaktadır. Nitekim, yapılan bir çalışmada, alçak tünellerde yetiştirilen domateste küllemelere karşı portakal ekstraktının Ampelomyces quisqualis preparatı ile kombine edildiğinde yüksek etkiye sahip olduğu bildirilmiştir (Bardin ve ark., 2014).

Sebze üretimi yapılan alanlarda hastalıklara konukçuluk eden bitkilerin de kontrol altına tutulması hastalıkla mücadelede önemlidir. Sonuç olarak domates, biber, kabak, patlıcan ve hiyarda küllemeye neden olan patojenlere karşı çifçiler bilinçlendirilmeli, kültürel mücadelenin yeterli olmadığı durumlarda, kabakgillerde ve patlıcangillerde külleme etmenine karşı $60 \mathrm{ml} / \mathrm{da}$ dozunda $\quad 75$ $\mathrm{g} / 1$ Fluxapyroxad $+50 \mathrm{~g} / 1$ Difenoconazole,
$50 \mathrm{ml} / 1001$ su dozunda $100 \mathrm{~g} / 1$ Penconazole, $50 \mathrm{ml} / 1001 \mathrm{su}$ dozunda $200 \mathrm{~g} / 1$ Boscalid + $100 \mathrm{~g} / 1 \mathrm{Kresoxim}-m e t h y l, 40 \mathrm{ml} / 1001 \mathrm{su}$ dozunda $250 \mathrm{~g} / 1$ Triadimenol, $75 \mathrm{ml} / 1001 \mathrm{su}$ dozunda $250 \mathrm{~g} / 1$ Azoxystrobin ve benzeri terkipli bitki koruma ürünlerinin kullanılması önerilmelidir. Böylece ekonomik açıdan önemli domates, biber, kabak, patlıcan ve hıyar ekiliş alanlarında, üreticilerin hastalı ile mücadele ederek verim kayıplarının önüne geçilebileceği düşünülmektedir (Anonim, 2017).

\section{Kaynaklar}

Agrios, G. N. (1997). Plant Pathology (4th ed.). Academic Press, San Diego.

Amano, K. (1986). Host Range and Geographical Distribution of the Powdery Mildew Fungi. Japan Scientific Societies Press, Tokyo.

Anonim, (2004). Crime Scene Investigatin with Powdery Mildew Fungi.

Anonim (2008a). Zirai Mücadele Teknik Talimatları. T.C. GIDA TARIM VE HAYVANCILIK BAKANLIĞI Tarımsal Araştırmalar ve Politikalar Genel Müdürlüğü. Zirai Mücadele Teknik Talimatları. Cilt 3,s. 68.Ankara.

Anonim (2008b). T.C. GIDA TARIM VE HAYVANCILIK BAKANLIĞI Tarımsal Araştırmalar ve Politikalar Genel Müdürlüğü. Zirai Mücadele Teknik Talimatları. Cilt 3,s. 29.Ankara.

Anonim

http://pnwhandbooks.org/plantdisease /pathogen-articles/pathogens-common many-plants/fungi/powdery-mildew-

diseases. Son erişim tarihi: 15.06.2016.

Anonim, (2016 b). Bitki Hastalıkları Standart İlaç Deneme Metotları. T.C. GIDA TARIM VE HAYVANCILIK BAKANLIĞI.http://www.tarim.gov.tr /TAGEM/Belgeler/Sitandard/SEBZE $\% 20$ HASTALIKLARI\%20STANDA RT\% $20 \%$ C4\%B0LA $\%$ C $3 \% 87 \% 20$ DENEME \%20METOTLARI.pdf. Son erişim tarihi: 14.06.2016.

Anonim (2017). T.C. GIDA TARIM VE HAYVANCILIK

BAKANLIĞI 
Tarımsal Araştırmalar ve Politikalar Genel Müdürlüğü. Örtüaltı Entegre Mücadele Teknik Talimatı s. 73.Ankara.

Anonim

https://www.tarimorman.gov.tr/Konul ar/Bitkisel-Uretim/Tarla-Ve-

Bahce-Bitkileri/Ortu-Alti-

Yetistiricilik (Son erișim tarihi: 03.05.2019).

Anonim

(2019b)

https://antalya.tarimorman.gov.tr/Men $\mathrm{u} / 75 /$ Antalyada-Tarim (Son erişim tarihi: 20.06.2019)

Bardin, M.D., Duffaud, L., Neu, M. \& Laurent, T. (2014). Combining various biological methods to control powdery mildew of tomato. http://agris.fao.org/agris-

search/search.do?recordID=FR20162

22588 (Son erişim tarihi: 10.11.2019).

Bilanger, R. R., Busnell, W. R., Bile, A. J. \& Carver, OT. L.W. (2002). The Powdery Mildews A Comprehensive Treatise. APS Press, St. Poul, MN.

Bitki Koruma Ürünleri Veri Tabanı, (2019). https://bku.tarim.gov.tr /Arama/Index (Son erişim tarihi:07.06.2019).

Blumer, S., (1933). Die Erysiphacean Miitteleuropas. Verlang von Gebr. Fretz. A.G.., Zürih, 483 pp.

Bora T. \& Karaca I. (1970). Bitki Hastalıkları Sürveyi, Kültür Bitkilerinde Hastalığın ve Zararın Ölçülmesi. Ege Üniversitesi Ziraat Fakültesi Yardımc1 Ders Kitabı, Yayın No: 167, Ege Üniversitesi Matbaas1, Bornova. $43 \mathrm{~s}$.

Braun, U. (1987). A monograph of the Erysiphales (powdery mildews). Beih Nova Hedwigia 89: 1-700

Braun, U., Cook, R.T.A. Inman, A.J. \& Shin. H.D. (2002). The Taxonomy of the Powdery Mildew Fungi. Pages 13-55 in: The Powdery Mildews: a Comprehensive Treatise, Berlanger, R.R., W.R. Bushnell, A.J. Dik, and T.L.W Carver (eds.). American Phytopathological Society, St Paul.

Braun, U. \& Cook, R.T.A. (2012). Taxonomic Manual of the Erysiphales (Powdery Mildews). CBS
Biodiversity Series II, CBS-KHAW Fungal Biodiversity Centre, Utrecht, The Netherlands.

Cohen, R., Burger, Y. \& Katzir, N. (2004). Monitoring physiological races of Podosphaera xanthii (syn. Sphaerotheca fuliginea), the causal agent of powdery mildew in cucurbits: Factors affecting race identification and the importance for research and commerce. Phytopathology: 32(2): 174-183.

Cook, R.T.A.. Inman, A.J. \& Billings, C. (1997). Identication and classication of powdery mildew anamorphs using light and scanning electron microscopy and host range data. Mycological Research, 101 (8): 9751002.

EPPO, (2019 a). Leveillula taurica (LEVETA). EPPO Global Database, https://gd.eppo.int/taxon/LEVETA (Son erişim tarihi: 25.06.2019).

EPPO, (2019 b). Oidium neolycopersici (OIDINL) EPPO Global Database, https://gd.eppo.int/taxon/OIDINL (Son erişim tarihi: 25.06.2019).

EPPO, $(2019 \quad$ c). Golovinomyces cichoracearum (ERYSCI). EPPO Global Database, https:/gd.eppo.int/taxon/ERYSCI (Son erişim tarihi: 20.06.2019).

EPPO, $(2019$ d). Podosphaera xanthii (PODOXA). EPPO Global Database, https://gd.eppo.int/taxon/PODOXA (Son erişim tarihi: 23.06.2019).

Erper, I., M. Turkkan, G.H. Karaca and G. Kilic, 2012. New hosts for Phyllactinia guttata in the Black Sea Region of Turkey. Scandinavian Journal of Forest Research, 27 (5): 432-437.

Erper I., G. Ozer, C. Kalkan, M. Turkkan, 2019. First report of powdery mildew caused by Erysiphe elevata on Catalpa bignonioides in Turkey. Journal of Plant Pathology, 101: 195.

Falk, S.P., Gadoury, D.M., Pearson, R.C. \& Seem, R.C. (1995). Partial control of grape powdery mildew by the mycoparasite Ampelomyces 
quisqualis. Plant Diseases, 79: 483490.

Hawker, L. E. (1966). Fungi. Hutchinson, London.

Heffer, V., Johnson, K.B. Powelson, M.L. \& Shishkoff. N. (2006). Identification of Powdery Mildew Fungi. The Plant Health Instructor.

Hijwegen, T. (1992). Biological control of cucumber powdery mildew with Tilletiopsis minor under greenhouse conditions. Netherlands Journal of Plant Pathology, 98: 221-225.

Horst, R.K. (2013). Field Manual of Diseases on Fruits and Vegetables. Springen, 131 p, London.

Jones, H., Whipps, J.M. \& Gurr, S.J. (2001). The tomato powdery mildew fungus Oidium neolycopersici. Molecular Plant Pathology, 2(6): 303-309.

Kabaktepe, Ş., Heluta, V.P. \& Akata, I. (2015). Checklist of powdery mildews (Erysiphales) in Turkey. Biological Diversity and Conservation, 8(1): 28146.

Kamenidou, S. (2005). Soluble SiliconBased Disease Management of Floricultural Crops. (M.Sc. Thesis, The Oklahoma State University Oklahoma).

Kandilci P. (2006). Adana Yöresi'nde Bitkisel Ürünlerde ve Yabancı Otlar Üzerinde Görülen Külleme Hastalıkları ve Etmenleri. (Yüksek Lisans Tezi, Çukurova Üniversitesi, Fen Bilimleri Enstitüsü)

Karman, M, (1971). Bitki Koruma Araştırmalarında Genel Bilgiler. Denemelerin Kuruluşu ve Değerlendirme Esasları. Bölge Ziraî Mücadele Araştırma Enstitüsü, İzmirBornova, $279 \mathrm{~s}$.

Kirbağ, S. \& Turan, N. (2005). Malatya'da Yetiştirilen Bazı Sebzelerde Görülen Mikrofungusların Tespiti. Firat Üniversitesi Fen ve Mühendislik Bilimleri Dergisi, 17(3): 559-564.

Kırbağ S. \& Kurşat, M. (2011). Sivrice (Elazı ğ) çevresindeki bitkiler üzerinde gelişen külleme fungus türleri. Artvin Çoruh Üniversitesi Orman Fakültesi Dergisi, 12(1): 9-14.
Kiss L, Cook R.T.A., Saenz, G.S., Cunnington, J.H., Takamatsu, S., Pascoe, I., Bardin, M., Nicot, P.C., Sato, Y. \& Rossman, A.Y. (2001). Identification of two powdery mildew fungi, Oidium neolycopersici sp. nov. and $O$. lycopersici, infecting tomato in different parts of the world. Mycological Research, 105: 684-697.

Kokie, S.T., Gladders, P. \& Paulus, A.O. (2007). Vegetable Diseases. Manson Publishing, 437 p, London.

Kontaxis, D.G. \& van Maren, A. (1978). Powdery mildew of tomato-a new disease in the United States. Plant Disease Report, 62: 892-893.

Maia, S.G. (2012). Isolation, Identification and Characterization of Cucurbit Powdery mildew in North Central Florida (Master Thesis, University of Florida, Graduate School)

Matsuda, S. \& Takamatsu, S. (2003). Evolution of host-parasite relationship of Golovinomyces (Ascomycete: Erysiphales) inferred from nuclear rDNA sequences. Molecular Phylogenetics and Evolution, 27: 314-327.

Ozan S. \& Maden S. (2005). Ankara ili domates ekiliş alanlarında yapraklarda hastalık oluşturan fungal etmenler, yaygınlıkları ve çıkış zamanları. Bitki Koruma Bülteni, 45(1-4): 45-54.

Ozan S. \& Maden S. (2006). Domateste görülen külleme hastalık etmenleri. Selçuk Üniversitesi Ziraat Fakültesi Dergisi, 20 (38): 126-135.

Ozan, S. \& Aşkın A. (2006). Orta Anadolu Bölgesi örtü altı sebze alanlarında görülen fungal hastalıklar üzerine çalışmalar. Bitki Koruma Bülteni, 46 (1-4): 65-75.

Russel, G.E. (1978). Plant Breeding for Pest and Disease Resistance. Butterworth and Co, London.

Salvucci, A., Aegerter, B.J., Miyao, E.M. \& Stergiopoulos, I. (2016). First report of powdery mildew caused by Oidium lycopersici in field-grown tomatoes in California. Plant Disease, 100 (7), https://doi.org/10.1094/PDIS-11-151362-PDN 
Sezer A., (2016). Findikta Külleme. http://www.unyetb.org.tr/upload/imag es/images/ files/Findik\%20KüllemeÜnye\%202016\%20pdf(1) (Son erişim tarihi: 25.05 .2019$)$

Takamatsu, S. (2004). Phylogeny and evolution of the powdery mildew fungi (Erysiphales, Ascomycota) inferred from nuclear ribosomal DNA sequences. Mycoscience, 45: 147-157.

Takamatsu, S., Matsuda, S., Niinomi S. \& Havrylenko, M. (2006). Molecular phylogeny supports a northern hemisphere origin of Golovinomyces (Ascomycota: Erysiphales). Mycological Research, 1 (10): 1093 1101.

Townsend, G. K. \& Heuberger, J. W. (1943). Methods for Estimating Losses Caused by Diseases in Fungicide Experiments. Plant Disease Report, 27: 340-343

TÜIK,, (2018). Antalya örtüaltı tarım alanlar1. http://www.tuik.gov.tr (Son erişim tarihi: 05.05.2019).

Wicks, T.J. \& Clare, B.G. (1981) Powdery mildew on tomatoes. Australasian Plant Pathology 10: 36-37.

Verhaar, M.A., Ostergaard, K.K., Hijwegen, T. \& Zadoks, J.C. (1997). Preventative and curative applications of Verticillium lecanii for biological control of cucumber powdery mildew. Biocontrol of Science and Technology, 7: 543-551.

Yamaoka, N. \& Takeuchi, Y. (1999). Morphogenesis of the powdery mildew fungus in water. Physiological and Molecular Plant Pathology, 54: 145-154.

Yarwood, C. (1957). Powdery mildews. The Botanical Review, 23, 235-301.

Yolageldi, L., Sin, B. \& Onogur, E. (2008). First report of Oidium neolycopersici on tomatoes in Turkey. Plant Pathology, 57: 373 doi: 10.1111/j.1365-3059.2007.01723.x

Yörükoğlu, B. (2011). Küçük Menderes Havzasında Salçalık Biberlerde Sorun Olan Fungal Hastalıkların Yaygınlık ve Yakalanma Oranlarının Belirlenmesine Yönelik Araştırmalar.
(Yüksek Lisans tezi, Ege Üniversitesi, Fen Bilimleri Enstitüsü)

Yücel S. (1994). Akdeniz Bölgesi örtüaltı sebze alanlarında görülen fungal hastalıklar. Bitki Koruma Bülteni, 34 (1-2): 23-34.

Yüceson, M. (2017). Yerel, Yabani ve Ticari Kabakgillerde Külleme Hastalik Etmenler, Podosphaera xanthii (=Sphaerotheca fluginea Pollachi) ve Golovinomyces cichoracearum (=Erysiphe cichoracearum D.C)'nin Belirlenmesi, Tanılanması ve $\mathrm{Bu}$ Patojenlere Karşı Dayanık1 Genotiplerin Araştırılması. (Yüksek Lisans Tezi, Akdeniz Üniversitesi, Fen Bilimleri Enstitüsü)

Zheng, Z., Nonomura, T., Bóka, K., Matsuda, Y., Visser, R. G. F., Toyoda, H., Kiss, L. \& Bai, Y. (2013). Detection and Quantification of Leveillula taurica Growth in Pepper Leaves. Phytopathology, 103: 623-632. 